\title{
Risk factors associated with mortality in young and long-lived older adults in Florianópolis, SC, Brazil
}

\author{
Fatores de risco associados à mortalidade em idosos jovens $\mathrm{e}$ \\ longevos de Florianópolis, SC, Brasil
}

Susana Cararo Confortin (https://orcid.org/0000-0001-5159-4062) ${ }^{1}$

Selma Regina de Andrade (https://orcid.org/0000-0001-7449-6860) ${ }^{1}$

Lariane Mortean Ono (https://orcid.org/0000-0002-7275-5942) ${ }^{1}$

Thamara Hubler Figueiró (https://orcid.org/0000-0001-6502-1396) ${ }^{1}$

Eleonora d'Orsi (https://orcid.org/0000-0003-2027-1089) ${ }^{1}$

Aline Rodrigues Barbosa (https://orcid.org/0000-0003-0929-7659) ${ }^{1}$
${ }^{1}$ Programa de PósGraduação em Enfermagem, Centro de Ciências da Saúde, Universidade Federal de Santa Catarina. Campus Universitário, Trindade. 88040900 -

Florianópolis, SC - Brasil susanaconfortin@gmail.com

\begin{abstract}
This article aims to investigate risk factors associated with mortality in young $(<80$ years) and long-lived ( $\geq 80$ years) older adults in Florianópolis. A longitudinal population-based study of 1702 older adults participants of the EpiFloripa Ageing Study. Deaths were identified through searches in the Mortality Information System. The probability of survival was estimated using the Kaplan-Meier and Log-Rank methods. The effect of risk factors for mortality was evaluated using Cox Regression models, adjusted for gender, family income, leisure physical activity, depressive symptoms, functional disability, falls, smoking, cardiovascular disease, stroke, and diabetes mellitus. The overall survival probability was $89.9 \%$ and $52.6 \%$ for the young and long-lived older adults, respectively. For younger older adults, the risk of death was higher for males, ex-smokers and those with moderate/severe disability. For the long-lived older adults, only those with depressive symptoms had a higher risk of death. These results reveal different risk profiles of death among younger and older adults and the need for a differentiated look in the health care of this population.
\end{abstract}

Key words Older adults, Mortality, risk Factors
Resumo O objetivo deste artigo é investigar os fatores associados à mortalidade em idosos jovens ( $<80$ anos) e longevos ( $\geq 80$ anos) de Florianópolis. Estudo longitudinal, de base populacional, realizado com 1.702 idosos participantes do Estudo EpiFloripa Idoso. Os óbitos foram identificados por meio de buscas no Sistema de Informação sobre Mortalidade. A probabilidade de sobrevida foi estimada por meio do método de Kaplan-Meier e Log-Rank. O efeito de fatores de risco para mortalidade foi avaliado usando-se modelos de Regressão de Cox, ajustados por sexo, renda familiar, atividade fisica de lazer, sintomas depressivos, incapacidade funcional, quedas, tabagismo, doença cardiovascular, acidente vascular encefálico e diabetes mellitus. A probabilidade de sobrevida geral foi de $89,9 \%$ e 52,6\% para os idosos mais jovens e longevos, respectivamente. Para os idosos mais jovens, o risco de óbito foi maior para o sexo masculino, os ex-fumantes e aqueles com incapacidade moderada/grave. Para os longevos, apenas aqueles com sintomas depressivos apresentaram maior risco de óbito. Esses resultados evidenciam perfis distintos de risco de óbito entre idosos mais jovens e longevos e a necessidade de olhar diferenciado no cuidado à saúde dessa população.

Palavras-chave Idoso, Mortalidade, Fatores de risco 


\section{Introduction}

The accelerated increase in the number older adults, especially the long-lived ( $\geq 80$ years), has instigated the knowledge of the factors that influence the development of diseases and factors that can lead to the early mortality of these individuals ${ }^{1}$. The identification of such diseases and factors when amenable to treatment or changes in behavior may contribute to the maintenance or recovery of health status, avoiding irreversible outcomes. Therefore, it should be considered that the risk factors themselves occur due to different causes, which involve complex aspects over the years such as socioeconomic characteristics, environmental and social conditions, and individual behavior ${ }^{2}$.

Regarding modifiable risk factors for early morbidity and mortality, it is known that the adoption of healthy life habits at middle age is related to the increase in life expectancy ${ }^{3,4}$. But it seems that the adoption of habits such as practicing leisure activities, not smoking, drinking less alcohol, not being overweight and following a correct diet, even in old age, is also capable of prolonging the survival of people aged 75 and over, even though there are chronic diseases ${ }^{5}$.

Studies conducted with Brazilian older adults patients sought to identify factors associated with mortality between this group longitudinally ${ }^{6}$ and transversally $y^{7,8}$. The association between self-reported health ${ }^{6}$, smoking ${ }^{8}$, income ${ }^{8}$ and frailty ${ }^{7}$ were detected. However, it is unclear whether these associations are applicable to both the young older adults and the long-lived older adults, as there are several peculiarities among these age groups. Thus, this study advances since it seeks to identify factors associated with mortality in the older adults in different age groups, in order to identify the profile of the deaths in a representative sample of older adults.

Although patterns of morbidity and mortality differ between populations and between age groups ${ }^{9}$, and despite the relevance of the theme, no Brazilian studies have been identified that evaluated risk factors for mortality stratified by age group (young and long-lived older adults). The determination of risk factors may contribute to the implementation or adjustment of public policies for prevention and health promotion. The data from the present study will allow a greater understanding of the influence of age in the determination of the mortality profile of the older adult population in the capital of Southern Brazil. Seeking such answers, the purpose of the present study was to investigate the risk factors associated with the mortality of young and longlived older adults in Florianópolis, Southern Brazil.

\section{Methods}

This is a prospective, population-based and home-based cohort study, entitled "EpiFloripa: health conditions of older adults in Florianópolis", older adults (60 years of age or older), living in the urban area of Florianópolis, Southern Brazil. The baseline was carried out in 2009/10 and the follow-up in 2013/14.

Detailed information about the study population, sample selection, and site characterization was previously published ${ }^{10}$, as well as the description of the sample according to the study follow-up status ${ }^{11}$.

In 2009/2010 a sampling was carried out in two stages. First stage, 80 (eighty in each decile of income) among the 420 urban census tracts of the municipality were drawn systematically. The units of the second stage were the households, drawn systematically. All the older adults residing in the households were drawn to participate in the study. Within the selected households, 1702 (baseline response rate of $89.1 \%$ ) older adults were interviewed. Of these, 217 deaths were detected, 159 were considered losses and 129 refusals, totaling 1197 (70.3\%) home interviews conducted in the follow-up (2013/2014).

\section{Dependent variable}

The dependent variable is the time to death, defined as the time in months between the date of the first interview and the death or follow-up date (date of the second interview or refusal).

Deaths were identified through searches in the Mortality Information System (SIM) of the Ministry of Health, made available by the Health Department of the State of Santa Catarina, concerning to individuals aged 60 years and over. These searches occurred at the beginning (before contacting the participants) and end of the follow-up interview cycle (2013/14). Information such as date and basic cause present in Declaration of Death were used.

In addition, deaths identified during the interview period were recorded according to the data provided by family members and their information confirmed, when possible, by SIM searches ${ }^{10}$. 


\section{Independent variables}

Sex, family income $(\leq 1$ minimum wages [MW]; > 1 to $3 \mathrm{MW}>3$ to $5 \mathrm{MW}$; 5 to $10 \mathrm{MW}$ e $>10 \mathrm{MW}$ [MW in 2010: R\$510.00]). The physical activity at leisure ${ }^{12}$ was assessed using the International Physical Activity Questionnaire (IPAQ) and categorized as active enough $(\geq 150$ minutes per week) and insufficiently active $(<150$ minutes per week). The smoking habit was investigated by the question $O(a) \operatorname{Sr}(a)$ fuma ou fumou cigarros? and categorized into never smoked, smoked and stopped smoking and currently smoking. The depressive symptoms ( $\geq 6$ : yes; $<6$ : no) were evaluated through the Geriatric Depression Scale (GDS-15) ${ }^{13}$. The functional disability (none, mild disability [disability in 1 to 3 activities] moderate/ severe disability [disability in 4 or more activities]), evaluated through the Brazilian Questionnaire on Multidimensional Functional Assessment adapted from the questionnaire Old Americans Resources and Services (BOMFAQ/OARS) ${ }^{14}$.

The history of falls was verified using the question: O Senhor(a) sofreu alguma queda (tombo) no último ano? (not suffered falls, suffered falls). Regarding the morbidities, were verified from the question Algum médico ou profissional de saúde já disse que o(a) Sr. (a) tem/teve...?, where there were three options for aggravations (questionnaire from the National Household Sample Survey - PNAD) - cardiovascular disease (heart disease and/or high blood pressure), cerebrovascular disease and diabetes mellitus.

Studies suggest that these variables may be associated with mortality in the older adults ${ }^{15-17}$.

\section{Statistical analysis}

The analytical sample of the present study was composed of all the older adults with a follow-up date, that is, the interviewees in the second wave, refusals, and deaths, totaling 1544 individuals. Participants were censored without final follow-up date, losses, and participants whose death was informed by the family member, but who did not have information about the date.

The follow-up time was calculated in months between the date of the first interview and the follow-up date (death, second interview or refusal). The survival time was estimated using the Kaplan-Meier. To compare the survival curves stratified was used Log-Rank test. The total follow-up time of the study was 63 months.

The sample was stratified by age in two age groups, older adults young ( $<80$ years) and long- lived ( $\geq 80$ years). To estimate the association between the independent variables and mortality, according to the groups, the semi-parametric model of Cox. Crude and adjusted Cox regressions, where all variables were included simultaneously in the model, were performed. All analyzes were conducted in the statistical package Stata SE 13.0 with the svy command, which considers the sample weights and the study design.

\section{Ethical aspects}

The EpiFloripa Ageing Study was approved by the Human Research Ethics Committee (CEPSH) of the Federal University of Santa Catarina (UFSC), both in the baseline, and in the follow-up. All interviewees received and signed the Free and Informed Consent Form before the interview.

\section{Results}

Of the 1702 baseline respondents, 1197 were interviewed again in the follow-up. There were 129 refusals, 159 were considered losses and 217 deaths. There were no statistically significant differences between the lost and interviewed older adults in relation to gender, family income in minimum wages, smoking habits and cardiovascular risk. The proportion of respondents was significantly lower for older, inactive older adults, with dependence for 4 or more activities of daily living, with depressive symptoms, who suffered a fall in the last year, with a greater number of morbidities, who reported cardiovascular disease and stroke or stroke (Data not shown $)^{11}$.

There was a loss of follow-up among the older adults of the sample only for the age variable, which was expected due to aging and survival bias. The overall survival probability was $89.9 \%$ for the young older adults and $52.6 \%$ for the long-lived older adults $(\mathrm{p}<0.001)$. Figure 1 shows the survival curves according to the age group.

Regarding the age groups, those young older adults reported being more physically active, smoking more and having fewer depressive symptoms, functional disability, falls, cardiovascular disease and cerebrovascular disease, about long-lived (Table 1).

Table 2 shows the characteristics of the young older adults who died and Cox Regression. In the crude analysis, male subjects, those with depressive symptoms, moderate/severe functional dis- 


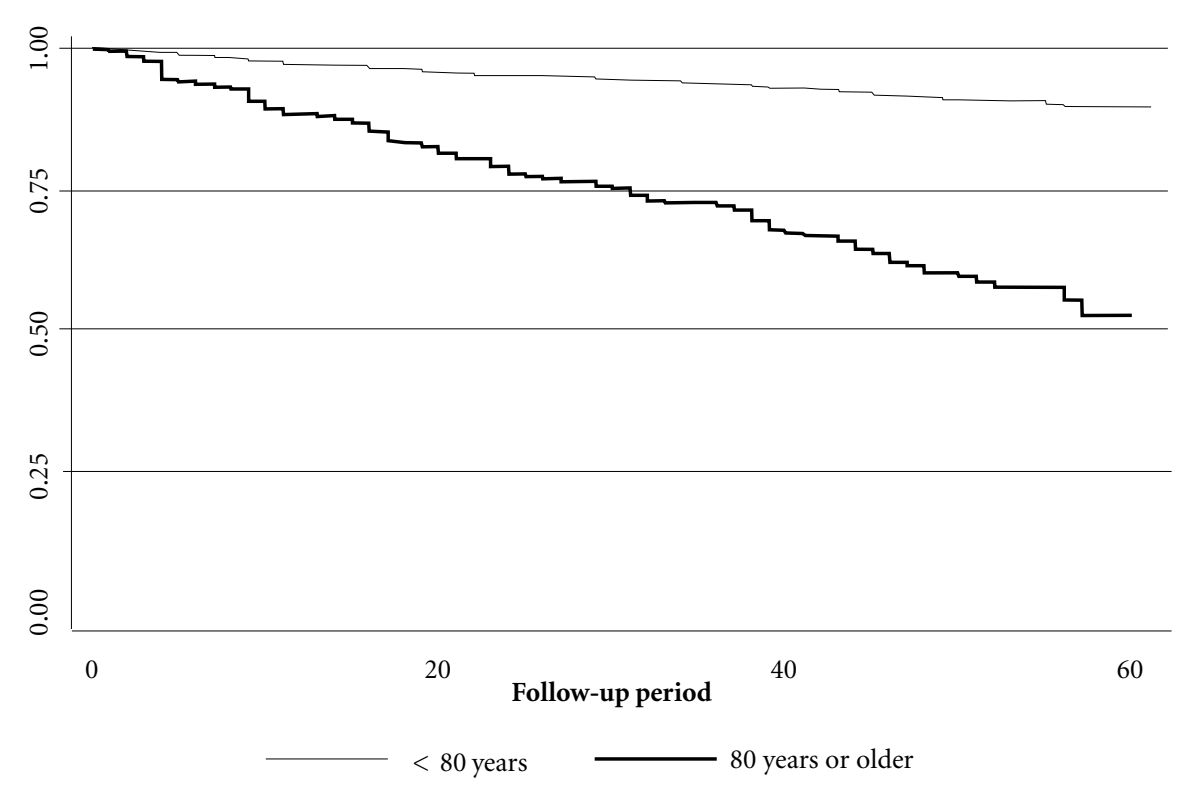

Figure 1. Survival curves stratified by age group.

ability, ex-smokers, those who had cerebrovascular disease and individuals with diabetes mellitus had a higher risk of death. After adjustment, only males (HR: 2.04; 95\%CI: 1.22-3.43), those with moderate/severe functional disability (HR: 2.97; 95\%CI: 1.10-8.04) and ex-smokers (HR: 1.79; 95\%CI: 1.10-2.93) maintained an association with a higher risk of death.

Among the long-lived older adults, those with depressive symptoms (HR: 2.54; 95\%CI: 1.424.56), moderate/severe functional disability (HR: 2.76; 95\% CI: 1.05-7.28), those who had cerebrovascular disease (HR: 1.81; 95\% CI: 1.13-2.92) presented higher risk of death in the crude analysis. In the adjusted analysis, only those with depressive symptoms remained associated, presenting a higher risk of death, when compared to their peers (HR: 2.03; 95\%CI: 1.15-3.58) (Table 3).

\section{Discussion}

This study found that adult old men, ex-smokers, and individuals with moderate/severe disability had a higher risk of mortality among those young older adults. While for the long-lived older adults, the risk of death was higher among those with depressive symptoms. Age is an immutable risk factor for mortality since the longer one lives, the greater the likelihood of death ${ }^{18}$. However, when reaching longevity the number of factors that increase the risk of death decrease.

The highest risk of death among men young older adults) confirms those found by Maia et al. ${ }^{9}$, in which the male sex is considered a risk factor for mortality. Women live longer than men. According to data from the World Health Organization (WHO), in 2016, the life expectancy of women was, on average, 73.8 years, while that of men was 69.1 years. According to Brazilian Institute of Geography and Statistics (IBGE), Brazilian women live 79.1 years and men 71.9 years. Another possibility is that men use fewer health services, especially regarding prevention actions, as well as hospitalizations are higher among women ${ }^{19}$. This means that men seek health care only when they already have the disease, leaving aside prevention and routine evaluations ${ }^{20,21}$. In addition, in general, there is still a higher prevalence of harmful health habits among men, such as smoking ${ }^{22}$ and excessive alcohol consump$\operatorname{tion}^{23}$, which are responsible for a wide range of diseases and health problems.

Regarding functional capacity, the older adults with moderate/severe disability presented a higher risk of mortality, as verified in previous studies $^{24-26}$. Functional capacity is considered one of the main markers of older adults' health and 
emerges in the current context as a key component for the evaluation of the health of this population, especially since it is a modifiable and preventable risk factor and interventions. The process of impairment of functional capacity involves not only the damage to physical health but also mental health, autonomy, social integration, family support and economic independence ${ }^{27}$.

Regarding smoking, the data indicated a significantly higher risk of mortality among former smokers of the younger age group ( $<80$ years), and this result is consistent with that found in previous studies ${ }^{28,29}$. A study with Chinese showed that being a former smoker was associated with a higher risk of death ${ }^{28}$. Similarly, in a meta-analysis performed by Gellert et al. ${ }^{29}$, which included 17 studies in several countries, showed that the mortality risk for the adults old in the age groups of 60 to 69 years, 70 to 79 years and 80 years or more was $1.54,1.36,1.27$, respectively, for ex-smokers.

The prevalence of smoking is decreasing worldwide, however, despite this reduction, the mortality burden of the population is still very high, corresponding in 2015 to $11.5 \%$ of deaths ${ }^{22}$. Smoking was considered the second risk factor for disability, causing 5.8 million deaths by the year $2013^{30}$, the result of deleterious effects on the health of tobacco, by several chemical elements that compose $\mathrm{it}^{31}$. Although the prevalence of habit is decreasing, its impact on the health of the population is high, suggesting that actions and policies aimed at combating and selling the product remain a major focus of governments.

The results showed that the long-lived older adults who presented depressive symptoms had a higher risk of mortality, as verified by other studies ${ }^{8,32}$, regardless of the scale used and/ or variation in the categorization of the scores that considered the depressive symptoms. In the PREHCO Study (Puerto Rican Elderly: Health Condition Study) conducted with 3,419 Puerto Ricans aged 60 and over ${ }^{32}$, individuals with depressive symptoms were more likely to die. In a city in Southeast Brazil (Amparo/SP), where 2,209 participants $(\geq 60 \text { years })^{8}$ were evaluated, the presence of depressive symptoms was associated with a higher chance of dying. One possible explanation for the finding is that fatigue, drowsiness and lack of initiative from depression (or depressive symptoms) negatively affect the health of the older adults, leading to the possibility of reduced functional capacity, as well as deteriorating health status and the quality of life of this population ${ }^{33-35}$. The comparison between
Table 1. Descriptive analysis of the initial sample of the study according to the analyzed variables and age group. Florianópolis, Santa Catarina, Brazil, 2009/2010.

\begin{tabular}{|c|c|c|c|}
\hline \multirow[t]{2}{*}{ Variables } & $\begin{array}{l}\text { Young } \\
\text { older } \\
\text { adults }\end{array}$ & $\begin{array}{l}\text { Long- } \\
\text { lived } \\
\text { older } \\
\text { adults }\end{array}$ & \multirow[t]{2}{*}{$\mathbf{p}$} \\
\hline & n (\%) & n (\%) & \\
\hline $\operatorname{Sex}(n=1701)$ & & & 0.138 \\
\hline Female & $927(61.7)$ & $160(67.1)$ & \\
\hline Male & $536(38.3)$ & $78(32.9)$ & \\
\hline $\begin{array}{l}\text { Family income } \\
\text { (minimum wages) ( } \mathrm{n} \\
=1651 \text { ) }\end{array}$ & & & 0.919 \\
\hline$\leq 1 \mathrm{MW}$ & $162(10.5)$ & $34(11.6)$ & \\
\hline$>1$ to $3 \mathrm{MW}$ & $381(26.4)$ & $53(24.5)$ & \\
\hline$>3$ to $5 \mathrm{MW}$ & $270(18.5)$ & $44(17.6)$ & \\
\hline$>5$ to $10 \mathrm{MW}$ & $330(23.8)$ & $51(22.9)$ & \\
\hline$>10 \mathrm{MW}$ & $277(20.7)$ & $49(23.3)$ & \\
\hline $\begin{array}{l}\text { Physical activity at } \\
\text { leisure }(\mathrm{n}=1701)\end{array}$ & & & $<0.001$ \\
\hline Active & $454(33.0)$ & $40(17.7)$ & \\
\hline $\begin{array}{l}\text { Insufficiently } \\
\text { active }\end{array}$ & $1009(67.0)$ & $198(82.3)$ & \\
\hline $\begin{array}{l}\text { Depressive symptoms } \\
(\mathrm{n}=1633)\end{array}$ & & & $<0.001$ \\
\hline No & $1099(78.6)$ & $133(59.8)$ & \\
\hline Yes & $321(21.4)$ & $80(40.2)$ & \\
\hline $\begin{array}{l}\text { Functional disability } \\
(\mathrm{n}=1701)\end{array}$ & & & $<0.001$ \\
\hline None & $440(28.5)$ & $17(7.3)$ & \\
\hline Mild disability & $647(45.6)$ & $61(27.1)$ & \\
\hline $\begin{array}{l}\text { Moderate / } \\
\text { severe disability }\end{array}$ & $376(25.9)$ & $160(65.7)$ & \\
\hline Falls $(\mathrm{n}=1701)$ & & & 0.001 \\
\hline No & $1203(83.0)$ & $176(74.2)$ & \\
\hline Yes & $260(17.0)$ & $62(25.8)$ & \\
\hline Smoking $(\mathrm{n}=1699)$ & & & 0.002 \\
\hline Never smoked & $879(58.6)$ & $157(66.0)$ & \\
\hline $\begin{array}{l}\text { Smoked and } \\
\text { stopped smoking }\end{array}$ & $448(32.0)$ & $74(31.9)$ & \\
\hline $\begin{array}{l}\text { Currently } \\
\text { smoking }\end{array}$ & $135(9.4)$ & $6(2.1)$ & \\
\hline $\begin{array}{l}\text { Cardiovascular } \\
\text { disease }(n=1701)\end{array}$ & & & 0.014 \\
\hline No & $504(35.6)$ & $64(25.8)$ & \\
\hline Yes & $959(64.4)$ & $174(74.2)$ & \\
\hline $\begin{array}{l}\text { Cerebrovascular } \\
\text { disease }(n=1700)\end{array}$ & & & 0.015 \\
\hline No & $1346(92.6)$ & $203(87.3)$ & \\
\hline Yes & $117(7.4)$ & $34(12.7)$ & \\
\hline Diabetes $(n=1701)$ & & & 0.551 \\
\hline No & $1137(78.7)$ & $189(76.9)$ & \\
\hline Yes & $326(21.3)$ & $49(23.1)$ & \\
\hline
\end{tabular}


Table 2. Descriptive and bivariate analysis of deaths and crude and adjusted Cox analysis for the young older adults, according to factors associated with mortality. Florianópolis, Santa Catarina, Brazil, 2013/2014.

\begin{tabular}{|c|c|c|c|c|c|}
\hline \multirow[t]{2}{*}{ Variables } & Total & Deaths & \multirow[t]{2}{*}{$\mathbf{p}$} & \multirow{2}{*}{$\begin{array}{c}\begin{array}{c}\text { Crude } \\
\text { analysis }\end{array} \\
\text { HR }(95 \% \mathrm{CI})\end{array}$} & \multirow{2}{*}{$\begin{array}{c}\begin{array}{c}\text { Adjusted } \\
\text { analysis }\end{array} \\
\text { HR }(95 \% \mathrm{CI})\end{array}$} \\
\hline & n (\%) & n (\%) & & & \\
\hline $\operatorname{Sex}(n=1272)$ & & & 0.006 & & \\
\hline Female & $804(63.2)$ & $59(6.8)$ & & 1 & 1 \\
\hline Male & $468(38.8)$ & $63(11.7)$ & & $1.70(1.11-2.61)$ & $2.04(1.22-3.43)$ \\
\hline Family income $(\mathrm{n}=1233)$ & & & 0.247 & & \\
\hline$\leq 1 \mathrm{MW}$ & $133(9.7)$ & $11(8.0)$ & & 1 & 1 \\
\hline$>1$ to $3 \mathrm{MW}$ & $327(25.9)$ & $38(10.4)$ & & $1.62(0.83-3.15)$ & $1.08(0.46-2.54)$ \\
\hline$>3$ to $5 \mathrm{MW}$ & $234(18.9)$ & $28(11.6)$ & & $2.00(0.89-4.48)$ & $1.30(0.55-3.09)$ \\
\hline$>5$ to $10 \mathrm{MW}$ & $287(24.0)$ & $24(6.7)$ & & $1.10(0.54-2.22)$ & $1.01(0.45-2.29)$ \\
\hline$>10 \mathrm{MW}$ & $252(21.5)$ & $16(6.0)$ & & $1.00(0.43-2.34)$ & $0.90(0.33-2.43)$ \\
\hline Laser physical activity $(\mathrm{n}=1272)$ & & & 0.099 & & \\
\hline Active & $387(32.7)$ & $24(6.5)$ & & 1 & 1 \\
\hline Insufficiently active & $885(67.3)$ & $98(9.8)$ & & $1.59(0.94-2.70)$ & $1.04(0.62-1.74)$ \\
\hline Depressive symptoms $(\mathrm{n}=1230)$ & & & $<0.001$ & & \\
\hline No & $952(78.6)$ & $65(5.9)$ & & 1 & 1 \\
\hline Yes & $278(21.4)$ & $47(17.1)$ & & $2.95(1.60-5.42)$ & $1.74(0.93-3.26)$ \\
\hline Functional disability $(\mathrm{n}=1272)$ & & & $<0.001$ & & \\
\hline None & $361(26.6)$ & $14(3.5)$ & & 1 & 1 \\
\hline Mild disability & $566(45.7)$ & $40(6.0)$ & & $1.65(0.67-4.03)$ & $1.24(0.52-2.94)$ \\
\hline Moderate / severe disability & $345(27.7)$ & $68(18.1)$ & & $5.48(2.31-12.99)$ & $2.97(1.10-8.04)$ \\
\hline Falls $(\mathrm{n}=1272)$ & & & 0.193 & & \\
\hline No & $1033(82.1)$ & $94(8.2)$ & & 1 & 1 \\
\hline Yes & $239(17.9)$ & $28(11.0)$ & & $1.41(0.90-2.20)$ & $0.97(0.58-1.63)$ \\
\hline Smoking $(\mathrm{n}=1149)$ & & & 0.002 & & \\
\hline Never smoked & $760(58.3)$ & $52(6.3)$ & & 1 & 1 \\
\hline Smoked and stopped smoking & $391(32.3)$ & $56(12.8)$ & & $2.06(1.28-3.32)$ & $1.79(1.10-2.93)$ \\
\hline Currently smoking & $120(9.4)$ & $14(9.3)$ & & $1.54(0.77-3.10)$ & $1.79(0.88-3.62)$ \\
\hline Cardiovascular disease $(\mathrm{n}=1272)$ & & & 0.006 & & \\
\hline No & $427(34.3)$ & $27(5.1)$ & & 1 & 1 \\
\hline Yes & $845(65.7)$ & $95(10.5)$ & & $2.08(1.10-3.60)$ & $1.50(0.73-3.07)$ \\
\hline Cerebrovascular disease $(n=1272)$ & & & $<0.001$ & & \\
\hline No & $1169(92.3)$ & $95(7.2)$ & & 1 & 1 \\
\hline Yes & $103(7.7)$ & $27(26.6)$ & & $3.93(2.14-7.19)$ & $1.76(0.87-3.55)$ \\
\hline Diabetes $(n=1272)$ & & & 0.003 & & \\
\hline No & $979(77.8)$ & $76(6.7)$ & & 1 & 1 \\
\hline Yes & $293(22.2)$ & $46(15.7)$ & & $2.50(1.35-4.64)$ & $1.49(0.77-2.87)$ \\
\hline
\end{tabular}

the studies can be made difficult by the different scales used, as well as by the variation in the categorization of the scores that consider the depressive symptoms. Differences in the profile of risk factors among younger and older adults can be explained by the fact that those with greater functional and health limitations die more and earlier. Thus, those who reach older age are less affected and do not show marked progressive decline ${ }^{36}$.

This study has some limitations. One limitation refers to the loss of follow-up, which is present in cohort studies, mainly with the older adults. The use of self-reported information and proxy respondents, which can generate information bias, are also limitations of the study. In ad- 
Table 3. Descriptive and bivariate analysis of deaths and crude and adjusted Cox analysis for the long-lived older adults, according to factors associated with mortality. Florianópolis, Santa Catarina, Brazil, 2013/2014.

\begin{tabular}{|c|c|c|c|c|c|}
\hline \multirow[t]{2}{*}{ Variables } & Total & Deaths & \multirow[t]{2}{*}{$\mathbf{p}$} & Crude analysis & $\begin{array}{l}\text { Adjusted } \\
\text { analysis }^{*}\end{array}$ \\
\hline & n (\%) & n (\%) & & HR $(95 \% C I)$ & HR $(95 \% C I)$ \\
\hline $\operatorname{Sex}(n=224)$ & & & 0.790 & & \\
\hline Female & $150(65.9)$ & $62(40.7)$ & & 1 & 1 \\
\hline Male & $74(34.1)$ & $33(42.8)$ & & $1.17(0.70-1.95)$ & $1.28(0.52-3.12)$ \\
\hline Family income $(\mathrm{n}=217)$ & & & 0.971 & & \\
\hline$\leq 1 \mathrm{MW}$ & $33(11.5)$ & $14(46.6)$ & & 1 & 1 \\
\hline$>1$ to $3 \mathrm{MW}$ & $50(24.5)$ & $21(43.4)$ & & $0.97(0.40-2.32)$ & $1.40(0.56-3.53)$ \\
\hline$>3$ to $5 \mathrm{MW}$ & $42(18.0)$ & $15(38.1)$ & & $0.81(0.26-2.53)$ & $0.89(0.27-2.88)$ \\
\hline$>5$ to $10 \mathrm{MW}$ & $46(22.1)$ & $18(38.8)$ & & $0.86(0.42-1.79)$ & $1.18(0.54-2.60)$ \\
\hline$>10 \mathrm{MW}$ & $46(23.9)$ & $24(41.8)$ & & $0.98(0.44-2.19)$ & $1.18(0.41-3.39)$ \\
\hline Physical activity at leisure $(\mathrm{n}=224)$ & & & 0.040 & & \\
\hline Active & $37(18.0)$ & $8(24.5)$ & & 1 & 1 \\
\hline Insufficiently active & $187(82.0)$ & $87(45.1)$ & & $2.12(0.99-4.52)$ & $1.91(0.75-4.86)$ \\
\hline Depressive symptoms $(\mathrm{n}=199)$ & & & 0.003 & & \\
\hline No & $122(59.7)$ & $38(28.8)$ & & 1 & 1 \\
\hline Yes & $77(40.3)$ & $42(56.3)$ & & $2.54(1.42-4.56)$ & $2.03(1.15-3.58)$ \\
\hline Functional disability $(\mathrm{n}=224)$ & & & 0.001 & & \\
\hline None & $15(7.0)$ & $3(23.3)$ & & 1 & 1 \\
\hline Mild disability & $57(26.5)$ & $15(23.9)$ & & $1.11(0.36-3.44)$ & $0.73(0.23-2.32)$ \\
\hline Moderate / severe disability & $152(66.5)$ & $77(50.3)$ & & $2.76(1.05-7.28)$ & $1.30(0.47-3.55)$ \\
\hline Falls $(\mathrm{n}=224)$ & & & 0.528 & & \\
\hline No & $165(74.1)$ & $67(39.9)$ & & 1 & 1 \\
\hline Yes & $59(25.9)$ & $28(45.7)$ & & $1.17(0.66-2.08)$ & $1.16(0.54-2.47)$ \\
\hline Smoking $(\mathrm{n}=223)$ & & & 0.695 & & \\
\hline Never smoked & $148(65.7)$ & $62(39.0)$ & & 1 & 1 \\
\hline Smoked and stopped smoking & 70 (324.) & $30(45.6)$ & & $1.29(0.75-2.21)$ & $1.21(0.53-2.77)$ \\
\hline Currently smoking & $5(1.9)$ & $2(44.1)$ & & $1.14(0.30-4.33)$ & $1.37(0.23-8.17)$ \\
\hline Cardiovascular disease $(n=224)$ & & & 0.922 & & \\
\hline No & $61(26.6)$ & $28(41.9)$ & & 1 & 1 \\
\hline Yes & $163(73.4)$ & $67(41.2)$ & & $1.00(0.62-1.61)$ & $1.16(0.60-2.22)$ \\
\hline Cerebrovascular disease $(\mathrm{n}=223)$ & & & 0.026 & & \\
\hline No & $190(86.6)$ & $76(38.3)$ & & 1 & 1 \\
\hline Yes & $33(13.4)$ & $18(57.2)$ & & $1.81(1.13-2.92)$ & $1.43(0.83-2.48)$ \\
\hline Diabetes $(\mathrm{n}=224)$ & & & 0.975 & & \\
\hline No & $178(76.6)$ & $78(41.3)$ & & 1 & 1 \\
\hline Yes & $46(23.4)$ & $17(41.7)$ & & $1.04(0.51-2.10)$ & $1.08(0.47-2.48)$ \\
\hline
\end{tabular}

Legend: HR = Hazard Ratio; 95\%CI: 95\% confidence interval; MW = minimum wages.

${ }^{*}$ Adjusted for sex, family income, physical activity at leisure, depressive symptoms, functional disability, falls, smoking, coronary disease, cerebrovascular disease, and diabetes.

dition, the present study was based on a single evaluation of the variables investigated, which may interfere with the real impact of the effects of these conditions on the risk of mortality, since they may vary over time. Furthermore, there are some limitations regarding the quality of information recorded in the SIM and Declaration of
Death, and the fact that the information analyzed is related only to the state of Santa Catarina.

It should be emphasized the adoption of a rigorous methodology, which allowed us to maintain the representativeness of the sample, according to gender, income, and age. The methodological rigor allowed to maintain a high re- 
sponse rate of the participants, besides making possible the reproducibility, since Kappa values of 0.6 to 0.9 were detected, which offers internal validity to the study.

\section{Conclusion}

The results obtained in the present study allow to conclude that the risk factors differ between the age groups and that the survival between the groups is significantly different. The identification and analysis of risk factors associated with mortality, according to age groups, allow a better understanding of the aging process and its influence on the health of the older adults. In addition, they facilitate the planning and di- rection of actions and care that meet the specific needs of this population. Prevention and early diagnosis should be the focus of public health actions to avoid the complications and negative outcomes resulting from these diseases.

The theme is of great relevance for public health, however, few studies evaluate the factors associated with the young and long-lived older adults. With the increase in the population life expectancy of Brazil, it is imperative to carry out new studies, stratified by sex, age group (60-69, $70-79,80-89,90$ or more), to find possible causes that can lead to avoidability of death or delaying death in the young and long-lived older adults. As well, in order to direct actions and public policies in these groups by the municipal / state managers.

\section{Collaborations}

SC Confortin, LM Ono, TH Figueiró, E d'Orsi, AR Barbosa and SR Andrade are responsible for the study concept and design, analysis and interpretation of data, drafting of the manuscript, revision and approval of the final version for publication and are responsible for all aspects pertaining to the entire article's accuracy and integrity. 


\section{References}

1. Rosset I, Pedrazzi E, Roriz-Cruz M, Morais EP, Partezani Rodrigues R. Tendências dos estudos com idosos mais velhos na comunidade: uma revisão sistemática (inter)nacional. Rev Escol Enf USP 2011; 45(1):264-271.

2. World Health Organization (WHO). Global health risks: mortality and burden of disease attributable to selected major risks. Geneva: WHO; 2009. [cited 2018 Jul 27] Available from: http://www.who.int/healthinfo/global_burden_disease/GlobalHealthRisks_report_full.pdf.

3. Yates LB, Djousse L, Kurth T, Buring JE, Gaziano JM. Exceptional longevity in men: modifiable factors associated with survival and function to age 90 years. Arch Intern Med 2008; 168(3):284-290.

4. Stenholm S, Head J, Kivimaki M, Kawachi I, Aalto V, Zins M, Goldberg M, Zaninotto P, Magnuson Hanson L, Westerlund H, Vahtera J. Smoking, physical inactivity and obesity as predictors of healthy and disease-free life expectancy between ages 50 and 75: a multicohort study. Int J Epidemiol 2016; 45(4):12601270 .

5. Rizzuto D, Orsini N, Qiu C, Wang H-X, Fratiglioni L. Lifestyle, social factors, and survival after age 75: population based study. BMJ 2012; 345:e5568.

6. Lima-Costa MF, Steptoe A, Cesar CC, Oliveira C, Proietti FA, Marmot M. The influence of socioeconomic status on the predictive power of self-rated health for 6-year mortality in English and Brazilian older adults: the ELSA and Bambui Cohort Studies. Ann Epidemiol 2012; 22(9):644-648.

7. Borim FSA, Francisco PMSB, Neri AL. Sociodemographic and health factors associated with mortality in community-dwelling elderly. Rev Saude Publica 2017; 51:42.

8. Ferreira TC, Coimbra AM, Falsarella GR, Costallat LT, Coimbra IB. Mortality in Brazilian community-dwelling older adults: 7 years of follow up in primary care. Geriatr Gerontol Int. 2016; 16(7):804-809.

9. Maia FOM, Duarte YAO, Lebrão ML, Santos JLF. Fatores de risco para mortalidade em idosos. Rev Saude Publica 2006; 40(6):1049-1056.

10. Schneider IJC, Confortin SC, Bernardo CO, Bolsoni CC, Antes DL, Pereira KG, Ono LM, Marques LP, Borges LJ, Giehl MWC, Krug RR, Goes VF, Boing AC, Boing AF, d'Orsi E. EpiFloripa Aging cohort study: methods, operational aspects, and follow-up strategies. Rev Saude Publica 2017; 51(104):1-10.

11. Confortin SC, Schneider IJC, Antes DL, Cembranel F, Ono LM, Marques LP, Borges LJ, Krug RR, d'Orsi E. Life and health conditions among elderly: results of the EpiFloripa Idoso cohort study. Epidemiol Serv Saude 2017; 26(2):305-317.

12. Craig CL, Marshall AL, Sjostrom M, Bauman AE, Booth ML, Ainsworth BE, Pratt M, Ekelund U, Yngve A, Sallis JF, Oja P. International physical activity questionnaire: 12-country reliability and validity. Med Sci Sports Exerc 2003; 35(8):1381-1395.

13. Almeida OP, Almeida SA. Reliability of the Brazilian version of the Geriatric Depression Scale (GDS) short form. Arq neuropsiquiatr 1999; 57(2B):421-426.
14. Blay SL, Ramos LR, Mari JJ. Validity of a Brazilian version of the Older Americans Resources and Services (OARS) mental health screening questionnaire. J Am Geriatric Soc 1988; 36(8):687-692.

15. Zhang Z, Xie D, Kurichi JE, Streim J, Zhang G, Stineman MG. Mortality Predictive Indexes for the Community-Dwelling Elderly US Population. J Gen Intern Med 2012; 27(8):901-910.

16. Taekema DG, Gussekloo J, Westendorp RG, de Craen AJ, Maier AB. Predicting survival in oldest old people. Am J Med 2012; 125(12):1188-94.e1.

17. Hirani V, Naganathan V, Blyth F, Le Couteur DG, Gnjidic D, Stanaway FF, Seibel MJ, Waite LM, Handelsman DJ, Cumming RG. Multiple, but not traditional risk factors predict mortality in older people: the Concord Health and Ageing in Men Project. Age 2014; 36(6):9732.

18. Ramos LR. Fatores determinantes do envelhecimento saudável em idosos residentes em centro urbano: Projeto Epidoso, São Paulo Determinant factors for healthy aging among senior citizens in a large city: the Epidoso. Cad Saude Publica 2003; 19(3):793-798.

19. Pinheiro RS, Viacava F, Travassos C, Brito AS. Gênero, morbidade, acesso e utilização de serviços de saúde no Brasil. Cien Saude Colet 2002; 7(4):687-707.

20. Ladwig KH, Marten-Mittag B, Formanek B, Dammann G. Gender differences of symptom reporting and medical health care utilization in the German population. Eur J Epidemiol 2000; 16(6):511-518.

21. Brasil. Ministério da Saúde (MS). Saúde Brasil 2007: uma análise da situação de saúde. Brasília: MS; 2007.

22. GBD 2015 Tobacco Collaborators. Smoking prevalence and attributable disease burden in 195 countries and territories, 1990-2013-2015: a systematic analysis from the Global Burden of Disease Study. Lancet 2015; 389(10082):1885-1906.

23. Rehm J, Dawson D, Frick U, Gmel G, Roerecke M, Shield KD, Grant B. Burden of disease associated with alcohol use disorders in the United States. Alcohol Clin Exp Res 2014; 38(4):1068-1077.

24. Landi F, Liperoti R, Russo A, Capoluongo E, Barillaro C, Pahor M, Bernabei R, Onder G. Disability, more than multimorbidity, was predictive of mortality among older persons aged 80 years and older. J Clin Epidemiol 2010; 63(7):752-759.

25. Santos JLF, Lebrão ML, Duarte YAO. Survival analysis and iniquities in older Brazilians: a six year follow up survey in São Paulo, Brazil. Int J Equity Health 2012; 11(Supl. 1):A8

26. St John PD, Tyas SL, Menec V, Tate R. Multimorbidity, disability, and mortality in community-dwelling older adults. Can Fam Physician 2014; 60(5):e272-280.

27. Lima AMM, Silva HS, Galhardoni R. Envelhecimento bem-sucedido: trajetórias de um constructo e novas fronteiras. Interface (Botucatu) 2008; 12(27):795-807

28. Lam TH, Xu L, Schooling CM, Chan WM, Lee SY, Leung GM. Smoking and mortality in a prospective cohort study of elderly Chinese in Hong Kong. Addiction 2015; 110(3):502-510

29. Gellert C, Schottker B, Brenner H. Smoking and allcause mortality in older people: systematic review and meta-analysis. Arch Intern Med 2012; 172(11):837844. 
30. GBD 2013 Risk Factors Collaborators. Global, regional, and national comparative risk assessment of 79 behavioural, environmental and occupational, and metabolic risks or clusters of risks in 188 countries, 1990-2013; 2013: a systematic analysis for the Global Burden of Disease Study 2013. Lancet 2015; 386(10010):2287-2323.

31. World Health Organization (WHO). The scientific basis of tobacco product regulation. Geneva: WHO; 2007. [cited 2018 Jul 27] Available from: http://www. who.int/tobacco/global_interaction/tobreg/who_tsr. pdf.

32. Downer B, Crowe M, Markides KS. Influence of Type II Diabetes and High Depressive Symptoms on the Likelihood for Developing Activities of Daily Living (ADL) Disability and Mortality in Older Puerto Ricans. J Aging Health 2017; 29(6):1079-1095.

33. Kondo N, Kazama M, Suzuki K, Yamagata Z. Impact of mental health on daily living activities of Japanese elderly. Prev Med 2008; 46(5):457-462.

34. Wada T, Ishine M, Sakagami T, Kita T, Okumiya K, Mizuno K, Rambo TA, Matsubayashi K. Depression, activities of daily living, and quality of life of community-dwelling elderly in three Asian countries: Indonesia, Vietnam, and Japan. Arch Gerontol Geriatric 2005; 41(3):271-280.

35. Millan-Calenti JC, Maseda A, Rochette S, Vazquez GA, Sanchez A, Lorenzo T. Mental and psychological conditions, medical comorbidity and functional limitation: differential associations in older adults with cognitive impairment, depressive symptoms and co-existence of both. Int J Geriatric Psych. 2011; 26(10):1071-1079.

36. White J, Zaninotto P, Walters K, Kivimaki M, Demakakos P, Shankar A, Kumari M, Gallacher J, Batty GD. Severity of depressive symptoms as a predictor of mortality: the English longitudinal study of ageing. Psychol Med 2015; 45(13):2771-2779.

Article submitted 29/05/2018

Approved 13/09/2018

Final version submitted 15/09/2018 